\title{
A FRAMEWORK TO ANALYSE THE QUALITY OF ECEC SERVICES ACCORDING TO THE CHILD-CENTRED CULTURE
}

\author{
Paolo Sorzio, \& Caterina Bembich \\ DiSU, University of Trieste (Italy)
}

\begin{abstract}
In this contribution it is proposed a critical framework, based on Basil Bernstein's theory, for two aims. The first one is a critical reflection on some structural limits of the Indicator Frameworks used to evaluate the quality of Early Childhood Education and Care services (ECEC), since they rely mainly on measures of the structural and processual characteristics of the educational settings. As a consequence, the processual dimensions are reduced to their individual components, overlooking the complex and contingent interactions that create opportunities for learning. The second aim is to propose a framework, based on Basil Bernstein's theory to analyse the different child-centred approaches to ECEC.
\end{abstract}

Keywords: Child-centredness, quality of services, indicator frameworks, reflective practice.

\section{Introduction}

According to Chung and Walsh (2000), three major perspectives on child-centred practices have historically evolved: Romantic, Developmentalist and Democratic. Each identifies the child as at the centre of the educational professional practices, characterised by the identification of each child's needs, competencies, interests. However, each perspective proposes one's own declination of what the child is at the centre of (Romantic: her/his world; developmentalist: the curriculum; democratic: the community).

\section{Criticising the quality indicator frameworks methodology}

In developing a Quality Framework, Policy Institutions have usually identified some structural and processual indicators, in order to signal the level of achievement in specific and relevant dimensions, according to given benchmarks.

The focus of this contribution is to question the validity of measures of the interactional processes, as well as reflecting about the potentiality of the introduction of qualitative evidence to promote quality and child-centredness in the Early Childhood Education and Care services.

Table 1. Relevant features usually incorporated in the Quality indicator frameworks.

\begin{tabular}{|l|l|l|}
\hline Structural factors: & Organisational factors & Process factors \\
\hline Finances & Staff qualifications & Staff responsiveness \\
\hline indoor/outdoor spaces & Staff/children ratios & $\begin{array}{l}\text { Structure and complexity of } \\
\text { tasks }\end{array}$ \\
\hline playing materials and furniture & Health/food regulations & Quality of social interactions \\
\hline Impact over the community & Design/documentation strategies & Children's attendance \\
\hline & $\begin{array}{l}\text { In-service teacher training and } \\
\text { action-research }\end{array}$ & Relationships with families \\
\hline
\end{tabular}

Early Years educational settings are evaluated according to standards, on the basis of simple measures typically obtained by using rating scales. However, there are methodological limits in the analysis of the educational processes: for example, frameworks such as CLASS (Pianta, La Paro and Hamre, 2008) and ECERS-R (Harms, Clifford and Cryer, 2004) are intended to single out and measure the dimensions that characterise complex processes such as respect of children's rights, promotion of good relationships between adults and children; non-invasive care; autonomy, respect for children's interests and emotions, close listening, joint meaning making, prosocial behaviours. CLASS and 
ECERS-R schemes evaluate isolated dimensions as proxies of complex and dynamic processes, therefore, they can be interpreted differently in different contexts.

Although the systematicity and elegance of many Quality Frameworks are to be appreciated, there are two critical points:

a) the Frameworks tend to merge the concept of "indicator" and the concept of "measure" (Alexander, 2008). Some measures of quality can be easily assessed (Space per child; teacher/children ratios; health quality of food; daily schedules); however, rating scales do not suffice to evaluate the child-centredness and the opportunities for learning, since they single-out individual dimensions from complex and dynamic processes of interaction;

b) "the distance" of the singled-out dimensions from the direct experiences of practitioners, children and families in their everyday practices (Erickson, 2006; Hammersley, 1995).

By confounding measures and indicators, the complexity of the child-centred pedagogy is overlooked. The 'construct validity' of the Quality Indicator Frameworks needs to be assessed through educational theories, rather than relying only upon the accountability logic. Furthermore, practitioners develop their professional activities in a context characterised by the specificity of settings, tools, norms and people, which make the situated conditions for the development of the curricular activities. As a consequence, from the point of view of the practitioners, each setting is a unique context of practice. The ranking of specific dimensions is only an information that must be interpreted.

\section{Developing an alternative framework based on Basil Bernstein's work}

By applying the concepts proposed by Basil Bernstein $(1973 ; 1999)$ to analyse the process of schooling to the Early Years sector, we identify a pattern of possibilities that offers opportunity to understand how the professionals organise in practice the child-centred perspective (implicit theories) in terms of the curriculum, interaction and documentation. This approach may complement the more established model of standard measures to evaluate the quality of ECEC services. dimensions:

According to Bernstein, the practices of schooling can be identified by intersecting three

a) Classification (the degree of insulation an element has in relation to others, for example: experiences in-school and out-of-school; the degree of separation of activities in the same educational practice). The higher the classification, the stronger is the instructional approach;

b) Framing: the degree of adult's control of the interaction; the higher the control of discourse by the adults is, the stronger is the teacher's voice; the higher the opportunities of children's contribution, the stronger the children's voices are valued;

c) Vertical and horizontal discourse is a dimension that can highlight some differences within the child-centred approach. The socio-constructivist approach, such as the Reggio Approach promotes a vertical discourse, since it is based not only on child-initiated activities and children interests, but also on higher order thinking strategies, such as planning, revision, communication.

Democratic and constructivist approaches in early childhood education are characterised by children's interests and inquiries, an exploratory talk, in which the adults extend the children's thoughts and contributions. Democratic approaches to child centred education give value to a variety of children's contributions through different sign systems (should they be verbal language, visual, dance, musical, etc) to make children participant in the ongoing dialogue of society and the authors of their own individual contribution to the conversation. In these contexts, the professionals adopt practices based on the principles of "children as active constructors of knowledge. In classrooms consistent with this theory, teachers provide direction and guidance as they assist children in developing their knowledge, but they also provide opportunities for children to direct their own explorations of objects and academic topics" (Stipek, 2004, p. 550). Characteristically, spaces are integrated and children can move freely, in order to overcome differences in gender, different abilities, ethnicity and to some extent in age. Each organised space can create the opportunity for children's initiative, rather than fragmenting curricular activities in simple and repetitive exercises (Low classification). Interactions tend to promote children's genuine contributions to joint activities, to emphasize democratic dialogue, reflection and metacognition, rather than imposing an instructional script (Low framing). Romantic and constructivist Child-centredness tend to diverge in the role of adults: the constructivist approach, such as in the Reggio Emilia experience, the teachers' questions are oriented to extend the children's thinking processes, in order to achieve more clarity and systematicity during the joint curricular activities aimed at the production of an artefact (Vertical discourse). In the Romantic perspective, adults let the children play and express their personal feelings and interests. 
Table 2. Different educational approaches according to Bernstein's theory.

\begin{tabular}{|c|c|c|c|}
\hline Educational approach: & Instructional & $\begin{array}{l}\text { Romantic Child- } \\
\text { centredness }\end{array}$ & constructivist \\
\hline classification & strong & weak & weak \\
\hline Principles & $\begin{array}{l}\text { Focus on the acquisition } \\
\text { of behaviour. Children } \\
\text { are not considered } \\
\text { competent in setting up } \\
\text { their own objectives and } \\
\text { strategies }\end{array}$ & $\begin{array}{l}\text { Variety of children's } \\
\text { behaviour is the object } \\
\text { of development. Not a } \\
\text { prescriptive scheme of } \\
\text { behaviour }\end{array}$ & $\begin{array}{l}\text { focus on promoting } \\
\text { personal growth rather } \\
\text { than on instructing } \\
\text { children. Children are } \\
\text { considered accountable } \\
\text { for selecting their own } \\
\text { projects and for } \\
\text { self-regulation }\end{array}$ \\
\hline Metaphor of learning & Learning as acquisition & Learning as exploration & $\begin{array}{l}\text { Learning as } \\
\text { construction }\end{array}$ \\
\hline Goals of education & $\begin{array}{l}\text { Children master } \\
\text { procedures for external } \\
\text { tasks. Focus on } \\
\text { correctness }\end{array}$ & $\begin{array}{l}\text { Well-being and } \\
\text { self-regulation }\end{array}$ & $\begin{array}{l}\text { Metacognitive } \\
\text { dispositions; higher } \\
\text { order thinking and } \\
\text { understanding }\end{array}$ \\
\hline Teaching/education & $\begin{array}{l}\text { A piecemeal approach } \\
\text { to learning. The } \\
\text { activities relate to } \\
\text { isolated elements of } \\
\text { learning. repetition; } \\
\text { memorization. }\end{array}$ & $\begin{array}{l}\text { Children conducted } \\
\text { global activities: they } \\
\text { set goals; select tools } \\
\text { and strategies }\end{array}$ & $\begin{array}{l}\text { Project-based learning; } \\
\text { children set up their } \\
\text { own goals and } \\
\text { collaborate; teachers } \\
\text { promote }\end{array}$ \\
\hline \multirow[t]{3}{*}{ Framing } & Strong/visible & Weak/invisible & Weak/visible \\
\hline & $\begin{array}{l}\text { Instructional script; } \\
\text { children's contributions } \\
\text { should be filled in a } \\
\text { prescriptive scheme; } \\
\text { they are predictable; the } \\
\text { expected answer }\end{array}$ & $\begin{array}{l}\text { less directive approach; } \\
\text { children are expected to } \\
\text { regulate peer group } \\
\text { relationships and } \\
\text { individual behaviour }\end{array}$ & $\begin{array}{l}\text { High variety of } \\
\text { scaffolding strategies, } \\
\text { since the children's } \\
\text { thinking processes are } \\
\text { the centre of the } \\
\text { educational practice }\end{array}$ \\
\hline & $\begin{array}{l}\text { The teacher models the } \\
\text { activity and has an } \\
\text { expected behaviour in } \\
\text { mind }\end{array}$ & $\begin{array}{l}\text { The teacher supports the } \\
\text { child-initiated activities; } \\
\text { gives freedom and } \\
\text { monitors behaviour }\end{array}$ & $\begin{array}{l}\text { The teacher: expands } \\
\text { children's activities; } \\
\text { promotes dialogue; } \\
\text { privileges meaningful, } \\
\text { that is goal-based } \\
\text { activities, in which } \\
\text { some relevant aspects } \\
\text { are highlighted in order } \\
\text { to promote learning }\end{array}$ \\
\hline Role of the teacher & Visible and directive & Invisible & Visible and dialogical \\
\hline
\end{tabular}

This approach may complement the evaluative model based on fixed standards with the practitioners' critical reflection about their practices. Qualitative analysis and documentation (Erickson 1987) may offer an evidentiary basis for:

- Recognising the specific conditions that hinder the children's participation and learning according to the child-centred practice, especially the constraints to the recognition of children's voices, rights and agency;

- Promoting collaborative design of educational activities, in order to encourage children's exploration, dialogue and thinking processes;

- Conducting action-research projects within the services, in order to promote joint reflection among practitioner, to enhance the professional resources in the service.

\section{Integrating the measurement approach with the insiders' reflective accounts}

The measurement approach can be considered conducted by a detached subject who applies standardised instruments to gather data which represent the magnitude of specific dimensions in a setting, in order to compare them with given standards. This distant evaluative look can be complemented with in-depth professionals' accounts in narrative terms. 
In Pastori and Pagani's research (2017), the introduction of Quality Frameworks tools offers a pattern of information that can guide the practitioners in a joint analysis of the interactional dynamics in the educational setting. The use of standardised tools can be considered as a trigger for educators' reflection, narrative accounts and change. Subsequently, Pastori and Pagani conducted a participatory action-research with professionals (2020), by introducing the Classroom Assessment Scoring System (CLASS - Pianta et al., 2008), with the aim of engaging the participants in a critical discussion of their practice. Participants reported some positive aspects in the use of the framework, such as the centrality of the educator-child relationship in defining the quality of the service and the focus on the emotional dimension of learning. On the other hand, there are some shortcomings: the framework lacks a deep focus on the interactional competence of children; it emphasizes productivity ("doing something"), rather than the opportunities for learning emerging during the educational activities (that is, posing the questions: "which are the meaningful, rich experiences for children?", "Why do some activities become learning experiences?").

\section{Conclusion}

The Quality Frameworks are useful tools to register a great amount of information about the magnitude of relevant dimensions of the Early Years educational settings. However, their usefulness relies in understanding their implicit rationales and as an opportunity to empower the practitioners, who are the principal agents to improve the internal quality of the setting. Through reflective documentation, practitioners can evaluate the quality of their child-centred practice, by recognising potential boundaries to the children's participation, the degree of control of the communication between adults and children, the opportunities for learning created by the curricular design, dialogic communication and meaningful experiences.

\section{References}

Alexander, R. (2008). Education for All, The Quality Imperative and the Problem of Pedagogy. CREATE Pathways to Access. Research Monograph n. 20. Institute of education, University of London

Bernstein, B. (1977). Class, Codes and Control, Vol. III: Towards a theory of educational transmissions. London: Routledge \& Kegan Paul.

Bernstein, B. (1999). "Vertical and horizontal discourse: An essay", in British Journal of Sociology of Education, 20 (2), 157-173.

Chung, S. and Walsh, D.J. (2000). "Unpacking child-centredness. A history of meanings", in Journal of Curriculum Studies, 32, (2), pp. 215-234.

Erickson, F. (1987). "Qualitative methods in research on teaching”, in M. C. Wittrock (ed.), Handbook of Research on Teaching, Macmillan, New York.

Erickson, F. (2006). "Studying side by side: Collaborative action ethnography in educational research", in G. Spindler, L. Hammond (eds.), Innovations in Educational Ethnography. Theory, Methods, and Results, Psychology Press, New York.

Hammersley, M. (1995). "Theory and evidence in qualitative research", in Quality and Quantity, 29, pp. 55-66.

Harms, T., Clifford, R.M. and Cryer, D. (2004). Early Childhood Environment Rating Scale. Revised. NY: Teachers College Press.

Pastori, G.G. and Pagani, V. (2017). "Is validation always valid? Cross-cultural complexities of standard based instruments migrating out of their context", in European Early Childhood Education Research Journal, 25 (5), pp. 682-697.

Pastori, G., \& Pagani, V. (2020). "Coniugare valutazione standardizzata e approccio partecipativo-riflessivo. Un'esperienza di ricerca collaborativa nei servizi per l'infanzia italiani”. https://boa.unimib.it/retrieve/handle/10281/276214/424926/6.\%20Valentina\%20Pagani\%2c\%20Gi ulia\%20Pastori.pdf [last consultation January the $7^{\text {th }} 2021$ ].

Pianta, R. C., La Paro, K. M. and Hamre, B. K. (2008). Classroom Assessment Scoring System Pre-K Manual. Baltimore: Brookes Publishing. 